\title{
SALESPERSON AUTHENTICITY AND GENDER-BASED PERCEPTIONS: AN INTERNATIONAL STUDY
}

\author{
Michael Stros \\ University of Applied Sciences and Arts of Southern Switzerland (SUPSI), Brig, Switzerland
}

Timothy Heinze

California State University, Chico, USA

David Říha

University of Economics, Prague, Czech Republic

Bodo Möslein-Tröppner

Duale Hochschule Ravensburg, Ravensburg, Germany

Elena Říhová

Skoda Auto University, Mlada Boleslav, Czech Republic

Lynn L. K. Lim

University of Applied Sciences and Arts Northwestern Switzerland, Olten

\begin{abstract}
Mirroring the increasing percentage of women in the professional workforce, the number of females in sales has dramatically risen in recent years. The growth of gender diversity within the world of B-to-B buying and selling requires an examination of potential gender effects associated with interpersonal communications. The latter influences perceptions of authenticity, which in turn, influence sales effectiveness. The current study uses an international sample to review interpersonal communication drivers that are associated with buyer perceptions of salesperson authenticity. Gender differences associated with the processing of body language and the spoken word are particularly examined. Results indicate that, in high-involvement sales situations, female perceptions of salesperson authenticity are highly influenced by salesperson body language. Male perceptions, conversely, are more heavily influenced by the spoken word. Implications for sales training are provided.
\end{abstract}

Keywords: sales, authenticity, gender, body language, spoken word

DOI: http://dx.doi.org/10.15549/jeecar.v7i1.398 


\section{INTRODUCTION}

In the United States, women now outnumber men in management, professional, and related occupations (Bureau of Labour Statistics, 2019). The trend is mirrored across the developed world (International Labour Organization, 2018). In sales, the number of women has grown exponentially, and women now play key roles in both buying and selling. However, potential gender differences associated with interpersonal communications and personality factors in sales have not been extensively studied (McQuiston \& Morris, 2009). The fact that interpersonal communications and personality factors in sales remains understudied (Erevelles \& Fukawa, 2013) is concerning since the personal interactions between salespeople and buyers affect sales effectiveness (Bush et al., 2002; Sheth \& Sisodia, 2002).

In sales situations, personal interaction factors influence consumers' perceptions of salesperson authenticity, which in turn, may influence consumers' sales receptivity (Stros, Heinze, \& Říha, 2017). Authenticity has been defined as "the unobstructed operation of one's true, or core, self in one's daily enterprise" (Kernis, 2003, p.13). Barrett-Lennard (1988) defined authenticity as "consistency between the three levels of (a) a person's primary experience, (b) their symbolized awareness, and (c) their outward behaviour and communication" (p. 82).

The current study focuses on perceptions of authenticity in high-involvement sales situations. Are male and female perceptions of salesperson authenticity driven by similar personal interaction factors? The study's research objective is to answer the question via examining the factors that drive each gender's perceptions of authenticity.

The current paper begins by reviewing personal authenticity and gender in relation to interpersonal communication factors. Next, a quasi-experimental design is presented. The design is influenced by Plouffe et al.'s (2008) call for experimental designs in sales research. The design involves an automotive sales experiment tested in a four-country convenience sample (Czech Republic, Germany, Switzerland, and the United States). Structural equation modelling (SEM) is used to analyse collected data. The paper concludes with a discussion which may be useful to sales managers who must train salespeople to operate effectively in today's climate of gender diversity.

\section{LITERATURE REVIEW}

The current section begins by discussing personal authenticity and the interpersonal communication factors that drive perceptions of authenticity. The section then reviews gender differences associated with interpersonal communications.

\section{Authenticity}

According to Freud (1938), personal authenticity results when an individual's emotional (affective), rational (cognitive), and physical (behavioural) characteristics are balanced. The physical component involves body language or other external, behavioural displays. The rational component involves displays of the mind and thinking, and the emotional component includes displays of feelings.

The effects associated with personal authenticity are largely positive. Not only is authenticity a strong predictor of personal wellbeing (Wood et al., 2008), but it can also improve performance across a wide variety of business settings. Authenticity even enhances the performance of individuals who are simply exposed to displays of authenticity (Algera \& Lips-Wiersma, 2012; Avolio \& Gardner, 2005; Avolio et al., 2004; Diddams \& Chang, 2012; Neider \& Schriesheim, 2011; Rego et al., 2011; Stros, Heinze, \& Říha, 2017; Tate, 2009; Walumbwa et al., 2010; Wood et al., 2008).

In sales, Stros, Heinze, and Říha (2017) determined that consumer perceptions of salesperson authenticity are primarily informed by body language (behaviour) and the spoken word (cognition). The emotional, or affective, factor does not significantly impact consumer perceptions of authenticity. The authenticity factor model (AFM) showcased that if a salesperson balances body language and the spoken word in a congruent manner, consumer perceptions of the salesperson's authenticity will be positively influenced and desirable sales outcomes will result (Stros, Heinze, \& Říha, 2017). In contrast, if the salesperson displays a lack of balance, negative consumer judgements 
and undesirable sales outcomes will result (see also Bauer, 2002).

In light of the general findings on authenticity, the current study explores specific interpersonal drivers of cognition and behavior and their resultant effect on perceptions of salesperson authenticity. The spoken word (cognition) is studied via the content (CO), organization (OR), style (ST), and tone (TO) of a salesperson's speech (see Stros, Heinze, \& Říha, 2017). Body language (behaviour) is studied via immediacy cues (IM), relaxation (RE), movement (MO), and facial patterns (FA) (see Mehrabian, 1969).

\section{Gender}

Across recent decades, researchers have debated the extent and degree to which gender variance exists. The current section reviews pertinent gender difference literature. First, macro notions of gender divergence are examined and are followed by specific reviews of gender differences related to cognition and behaviour.

During the 1960s and 70s, feminist research attempted to downplay gender differences (Grant, 1988). Empirical research in the 1980s and $90 \mathrm{~s}$ discredited the effort, but the downplaying of gender differences resurfaced in the form of gender similarity hypothesis (Hyde, 2005; Zell et al., 2015). Relying on meta-analyses of gender difference literature, proponents of gender similarity hypothesis have argued that gender dissimilarities are nominal at best. Rather, the two genders are more similar than dissimilar.

Critics of gender similarity hypothesis respond that although the genders may be more similar than dissimilar across a broad array of variables, the point is largely meaningless. For example, the DNA of humans and bonobos is 99\% similar, but this similarity does not indicate that humans and bonobos are the same or that their interactions are not dramatically influenced by the $1 \%$ (Zuriff, 2015). Critics contend that the core weakness of gender similarity hypothesis is that it relies on meta-analyses which give equal weighting to interpersonally meaningful and non-meaningful variables. For example, although the genders vary significantly in relation to interpersonally meaningful items such as assertiveness (Twenge, 1997), there is minimal gender variation in relationally non-meaningful items such as time duration judgement (Block, Hancock, \& Zakay, 2000). However, gender similarity hypothesis includes both assertiveness and time duration judgement as co-equal variables. Through including a large number of relationally insignificant variables, the hypothesis dilutes many significant variance factors (e.g. assertiveness, independence, understanding of others, gentleness, etc.). The net result is a blunt instrument that does not enable precise analysis of gender-based interpersonal communication factors (Zuriff, 2015).

The use of surgical instruments in genderbased interpersonal communication analysis has resulted in the suggestion that the genders vary significantly across an array of relationally meaningful variables. These differences, across multiple decades, have been extensively documented (Hall, 2006). Two competing theories have attempted to explain the variation. Gender socialization theory (or social role model theory) suggests that gender variance is fundamentally a function of divergent socialization methods (Eagly, 1987). For example, Henley (1977) attempted to explain differences in nonverbal communications through highlighting the manner in which males and females are socialized differently in relation to power and dominance. Trait theorists, conversely, view gender variance as primarily stemming from innate, biological differences (Buss, 1995; Michalski \& Shackelford, 2010; Pool, 1994); a conclusion drawn from research which showcases significant gender differences in early childhood before social acculturation has wielded a measurable effect (Else-Quest et al., 2006; McClure, 2000). Combining perspective from social role model and trait theorists, Abele's (2000) dual adaptation model suggests that both social role models and innate biological factors inform gender differences.

With respect to body language, the genders vary in the physical manner by which they express themselves and in the interpretations that they assign to body language (Hall, 1978 \& 2006; Koppensteiner \& Grammer, 2011; McClure, 2000; Vrugt \& Luyerink, 2000). Regarding the latter, some early research uncovered relatively insignificant gender differences associated with the interpretation of non-verbal cues (Coleman 1949, Davitz, 1964; 
Maccoby \& Jacklin, 1974; Wesgerber, 1956). However, methodological issues plagued many of these studies (Hall, 1978) and the majority of research indicates that females are substantially more inclined to assess non-verbal communications and are more advanced in their ability to interpret non-verbal communications (Briton \& Hall, 1995; Hall, 1978 \& 2006; Guadagno \& Cialdini, 2007; Kotlyar \& Ariely, 2013; LaFrance \& Henley, 1994; McClure, 2000; Rosen et al., 2008). Hall (1984) speculates that females' historically submissive role has increased their needs and motives to "understand subtle interpersonal cues" (p.14). Therefore, we hypothesize that:

H1: Salesperson body language influences female consumers' perceptions of salesperson authenticity more than it influences male consumers' perceptions of authenticity.

In relation to the spoken word, males and females process marketing messages differently in low involvement situations characterized by message cue congruity (Meyers-Levy \& Maheswaran, 1991; Meyers-Levy \& Sternthal, 1991). Women tend to utilize a detailed information processing approach which focuses on central cues, and men tend to process appeals via peripheral cues and the interpretation of those cues via pre-existing schemas (MeyersLevy \& Zhu, 2010; Papyrina, 2015; Putrevu, Tan, \& Lord, 2004). However, in high-involvement situations, men outperform females in the use of central cues to identify and process subject matter content (Kiecker, Palan, \& Areni, 2000). Additionally, in high involvement situations, men are more likely to resort to rational analysis of central (spoken or written word) cues (Guadagno \& Cialdini, 2007). Since the current study examines a high-involvement product purchase (automobile), we hypothesize that:

H2: A salesperson's spoken words influence male consumers' perceptions of salesperson authenticity more than they influence female consumers' perceptions of authenticity.

\section{METHODOLOGY}

The current study utilized a quasiexperimental design which included video observations and subsequent questionnaires.
Four two-minute sales videos were produced (Stros, Heinze \& Ǩíha, 2017). Professional actors, playing the roles of male and female automotive salespeople, were used in the videos. Each video presented a sales situation in which the salesperson displayed positive or negative affect (emotional expressions), behaviour (body language), and cognition (spoken word). The videos utilized "over-the-shoulder" camera shots so that viewers could only observe the torso and head of the salesperson. Each video included multiple elements of a typical personal sales interaction (welcome, needs assessment, product presentation, pre-close, etc.).

The four videos were shown to a sample of 1,421 university students who were potential automotive consumers. Sampled students were drawn from public universities in California, USA (443 participants); Prague, Czech Republic (478 participants); Ravensburg, Germany (703 participants); and Zurich, Switzerland (154 participants). After watching each video, student participants were asked to complete a 26-item survey. Survey responses were recorded both electronically and on hardcopy questionnaires. Approximately $65 \%$ of respondents were male. For a detailed discussion of the experiment and survey design/content, please see Stros, Heinze \& Říha (2017).

\section{DATA ANALYSIS}

1 Collected data was assessed for outliers, missing values, skewness and kurtosis. All tested values were within the acceptable range, according to Bortz and Doering (2006). Sample size was sufficiently large (Hair et al., 1995; Tabachnick \& Fidell, 2007), and the data was normally distributed (Fabrigar et al., 1999). Missing values (less than $2 \%$ of responses) were replaced by mean values of the variable in question (Hair et al., 2009; Howell, 2007; Little \& Rubin, 2002). The data was then factor analysed. Factor analysis is a multivariate statistical method which can be used in applied research for data reduction, instrument development, and trait identification.

2 Structural equation modelling (SEM), also known as covariance structural analysis or causal modelling, was used to test the hypothesized relationships in the proposed 
model (see Figure 1). SEM enables the simultaneous estimation of multiple regression equations in a single framework and allows for the investigation of relationships between evident (observed) and hidden variables. The current study's model was fitted using lavaan version 0.6-4 (Rosseel, 2012) in $\mathrm{R}$ version 3.6.1 ( $\mathrm{R}$ Core Team, 2019). The model was estimated using the maximum likelihood method. The latent factors were standardized, allowing for a free estimation of loaded factors.
3 Model fit statistics indicated a good model fit (see Table 1). Table 1 also displays the recommended values of various model fit measures. Some statisticians (e.g., Klein, 2010) argue that the chi-squared test of model fit is useful for evaluating the quality of a model. Chin and Todd (1995) and Bentler (1990) recommend a desired range for RMSEA $(<0.08)$, TLI $(>0.9)$, CFI $(>0.95)$ and SRMR values $(\leq 0.08)$.

Figure 1. Sales Situation Interaction Model (Source: Authors)

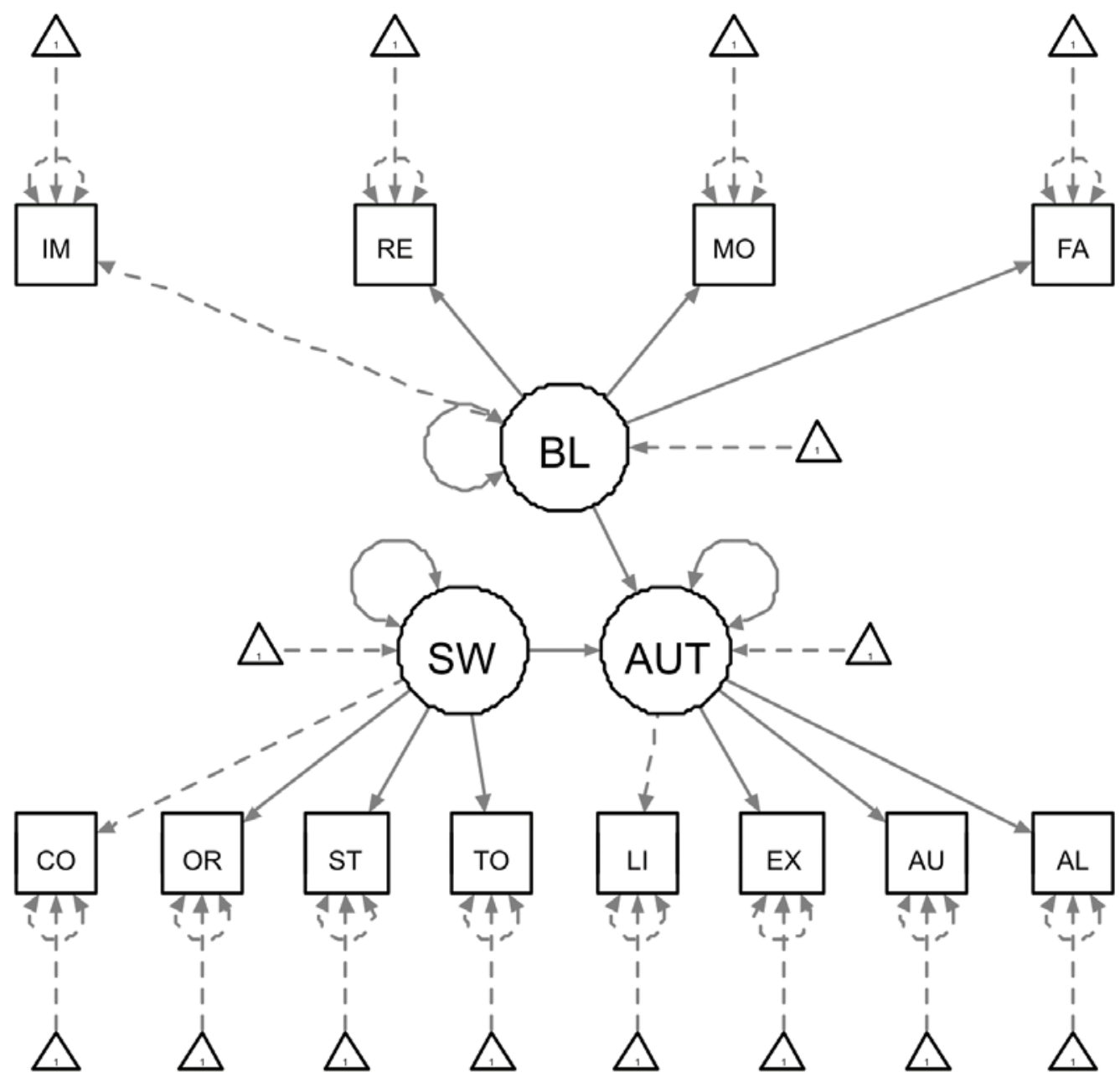

Standards for an "acceptable" level of model fit may differ across disciplines ( $\mathrm{Hu} \&$ Bentler,
1999). The values of the current study's models are within commonly accepted ranges. 
Table 1. Model Fit Statistics (Source: Authors)

\begin{tabular}{|l|l|c|c|}
\hline Model Fit Statistics & & $\begin{array}{c}\text { Model “Male" } \\
\text { Values }\end{array}$ & $\begin{array}{c}\text { Model "Female" } \\
\text { Values }\end{array}$ \\
\hline Number of observations & & 931 & 346 \\
\hline P-value & Chi-squared & 0.000 & 0.000 \\
\hline Comparative fit index & CFI & 0.982 & 0.914 \\
\hline Tucker-Lewis index & TLI & 0.977 & 0.889 \\
\hline Root mean square error of approximation & RMSEA & 0.094 & 0.119 \\
\hline Standardized Root Mean Square Residual & SRMR & 0.072 & 0.111 \\
\hline
\end{tabular}

Table 2 displays the results associated with the "male" data set. The first column (Estimate)

contains the parameter value (estimated or fixed) for each model parameter.

Table 2. Model "Male" Factor Loadings and Regressions (Source: Authors)

\begin{tabular}{|l|l|r|r|r|r|r|}
\hline Latent Variable & Factor/Variable & $\begin{array}{c}\text { Estimate } \\
(\boldsymbol{\beta})\end{array}$ & Std. err. & z-value & $\mathbf{p}(>|\mathbf{z}|)$ & Std. all. \\
\hline FACTOR LOADINGS & & & & & \\
\hline BL (Body Language) & IM(Immediacy Cues) & 1.000 & n.a. & n.a. & n.a. & 1.099 \\
\hline BL (Body Language) & RE (Relaxation) & -0.736 & 0.026 & -28.321 & 0.000 & -0.809 \\
\hline BL (Body Language) & MO (Movement) & -0.721 & 0.032 & -22.832 & 0.000 & -0.793 \\
\hline BL (Body Language) & FA (Facial) & 0.294 & 0.028 & 10.658 & 0.000 & $\mathbf{0 . 3 2 3}$ \\
\hline SW (Spoken Word) & CO (Content) & 1.000 & n.a. & n.a. & n.a. & 0.721 \\
\hline SW (Spoken Word) & OR (Organization) & 1.216 & 0.029 & 42.615 & 0.000 & $\mathbf{0 . 8 7 7}$ \\
\hline SW (Spoken Word) & ST (Style) & 1.124 & 0.025 & 44.084 & 0.000 & $\mathbf{0 . 8 1 1}$ \\
\hline SW (Spoken Word) & TO (Tone) & 0.863 & 0.025 & 34.533 & 0.000 & $\mathbf{0 . 6 2 3}$ \\
\hline $\begin{array}{l}\text { AUT (Authentic } \\
\text { Perception) }\end{array}$ & LI (Living) & 1.000 & n.a. & n.a. & n.a. & 0.868 \\
\hline $\begin{array}{l}\text { AUT (Authentic } \\
\text { Perception) }\end{array}$ & $\begin{array}{l}\text { EX (External } \\
\text { Influence) }\end{array}$ & 0.769 & 0.036 & 21.302 & 0.000 & $\mathbf{0 . 6 6 8}$ \\
\hline $\begin{array}{l}\text { AUT (Authentic } \\
\text { Perception) }\end{array}$ & $\begin{array}{l}\text { AU (Self- } \\
\text { authentication) }\end{array}$ & 0.339 & 0.034 & 10.023 & 0.000 & $\mathbf{0 . 2 9 4}$ \\
\hline $\begin{array}{l}\text { AUT (Authentic } \\
\text { Perception) }\end{array}$ & AL (Self-alienation) & 0.579 & 0.033 & 17.575 & 0.000 & $\mathbf{0 . 5 0 2}$ \\
\hline REGRESSIONS & & & & & & \\
\hline $\begin{array}{l}\text { AUT (Authentic } \\
\text { Perception) }\end{array}$ & BL (Body Language) & -0.154 & 0.030 & -5.180 & 0.000 & $-\mathbf{0 . 1 9 5}$ \\
\hline $\begin{array}{l}\text { AUT (Authentic } \\
\text { Perception) }\end{array}$ & SW (Spoken Word) & 0.726 & 0.033 & 22.220 & 0.000 & $\mathbf{0 . 6 0 4}$ \\
\hline
\end{tabular}

The second column (Std.err.) contains the standard error for each estimated parameter, and the third column (z-value) contains the Wald statistic (obtained by dividing the parameter value by its standard error). The fourth column $(\mathrm{p}(>|\mathrm{z}|))$ contains the $\mathrm{p}$-value for testing the null 
hypothesis that the parameter equals zero in the population. The last column (Std.all.) presents the completely standardized relevant coefficient.
Table 3 displays the results associated with the "female" data set. Factor loadings and regressions are shown in Table 3.

Table 3. Model "Female" Factor Loadings and Regressions (Source: Authors)

\begin{tabular}{|c|c|c|c|c|c|c|}
\hline Latent Variable & Factor/Variable & $\begin{array}{l}\text { Estimate } \\
(\boldsymbol{\beta})\end{array}$ & Std.err. & z-value & $\mathrm{p}(>|\mathrm{z}|)$ & Std.all. \\
\hline \multicolumn{7}{|l|}{ FACTOR LOADINGS } \\
\hline $\begin{array}{l}\text { BL } \\
\text { (Body Language) }\end{array}$ & $\begin{array}{l}\text { IM } \\
\text { (Immediacy Cues) }\end{array}$ & 1.000 & n.a. & n.a. & n.a. & 1.101 \\
\hline $\begin{array}{l}\text { BL } \\
\text { (Body Language) }\end{array}$ & $\begin{array}{l}\text { RE } \\
\text { (Relaxation) }\end{array}$ & -0.729 & 0.062 & -11.827 & 0.000 & -0.803 \\
\hline $\begin{array}{l}\text { BL } \\
\text { (Body Language) }\end{array}$ & $\begin{array}{l}\text { MO } \\
\text { (Movement) }\end{array}$ & -0.609 & 0.049 & -12.383 & 0.000 & -0.670 \\
\hline $\begin{array}{l}\text { BL } \\
\text { (Body Language) }\end{array}$ & $\begin{array}{l}\text { FA } \\
\text { (Facial) }\end{array}$ & 0.004 & 0.044 & 0.098 & 0.922 & 0.005 \\
\hline $\begin{array}{l}\text { SW } \\
\text { (Spoken Word) }\end{array}$ & $\begin{array}{l}\text { CO } \\
\text { (Content) }\end{array}$ & 1.000 & n.a. & n.a. & n.a. & 0.739 \\
\hline $\begin{array}{l}\text { SW } \\
\text { (Spoken Word) }\end{array}$ & $\begin{array}{l}\text { OR } \\
\text { (Organization) }\end{array}$ & 1.206 & 0.053 & 22.801 & 0.000 & 0.892 \\
\hline $\begin{array}{l}\text { SW } \\
\text { (Spoken Word) }\end{array}$ & $\begin{array}{l}\text { ST } \\
\text { (Style) }\end{array}$ & 1.078 & 0.045 & 23.823 & 0.000 & 0.797 \\
\hline $\begin{array}{l}\text { SW } \\
\text { (Spoken Word) }\end{array}$ & $\begin{array}{l}\text { TO } \\
\text { (Tone) }\end{array}$ & 0.748 & 0.051 & 14.786 & 0.000 & 0.553 \\
\hline $\begin{array}{l}\text { AUT } \\
\text { (Authentic Perception) }\end{array}$ & $\begin{array}{l}\text { LI } \\
\text { (Living) }\end{array}$ & 1.000 & n.a. & n.a. & n.a. & 0.851 \\
\hline $\begin{array}{l}\text { AUT } \\
\text { (Authentic Perception) }\end{array}$ & $\begin{array}{l}\text { EX } \\
\text { (External Influence) }\end{array}$ & 0.845 & 0.060 & 13.971 & 0.000 & 0.719 \\
\hline $\begin{array}{l}\text { AUT } \\
\text { (Authentic Perception) }\end{array}$ & $\begin{array}{l}\text { AU } \\
\text { (Self-authentication) }\end{array}$ & 0.231 & 0.048 & 4.810 & 0.000 & 0.197 \\
\hline $\begin{array}{l}\text { AUT } \\
\text { (Authentic Perception) }\end{array}$ & $\begin{array}{l}\mathrm{AL} \\
\text { (Self-alienation) }\end{array}$ & 0.659 & 0.054 & 12.206 & 0.000 & 0.561 \\
\hline \multicolumn{7}{|l|}{ REGRESSIONS } \\
\hline $\begin{array}{l}\text { AUT } \\
\text { (Authentic Perception) }\end{array}$ & $\begin{array}{l}\text { BL } \\
\text { (Body Language) }\end{array}$ & $\begin{array}{l}-0.193 \\
\end{array}$ & 0.048 & -3.976 & 0.000 & -0.249 \\
\hline $\begin{array}{l}\text { AUT } \\
\text { (Authentic Perception) }\end{array}$ & $\begin{array}{l}\text { SW } \\
\text { (Spoken Word) }\end{array}$ & 0.596 & 0.058 & 10.351 & 0.000 & 0.517 \\
\hline
\end{tabular}

The model assumes authentic perception as a central criterion for the sales decision (see also Říha, Heinze \& Stros, 2017; Stros, Heinze \& Říha, 2017). Results indicate two relevant paths for both data sets (i.e. "male" and "female"). Despite the fact that a difference in the weighting of the factors relevant to a purchase decision was identified for both genders, factor relationships were generally similar. The data also revealed that body language (BL) has a negative influence on perceptions of salesperson authenticity (AUT). A positive significant relation was uncovered between perceptions of authenticity (AUT) and the spoken word (SW), which means that the salesperson's spoken words positively influence perceptions of authenticity (AUT). 
Additionally, the relevant factors of the latent variables (AUT, BL and SW) were identified.

To identify potential gender differences, the standardized coefficients (Std.all.) for "male" and "female" data were compared by determining the actual differences as a percentage of the values (see Table 4).

Table 4. Factor Loadings Model Comparison (Source: Authors)

\begin{tabular}{|c|c|c|c|c|c|}
\hline Latent Variable & Factor/Variable & $\begin{array}{l}\text { Model } \\
\text { "Male" } \\
\text { Std. all. }\end{array}$ & $\begin{array}{l}\text { Model } \\
\text { "Female" } \\
\text { Std. all. }\end{array}$ & $\begin{array}{l}\text { Model } \\
\text { Difference }\end{array}$ & $\begin{array}{l}\text { Model } \\
\text { Difference } \\
{[\%]}\end{array}$ \\
\hline \multicolumn{6}{|l|}{ FACTOR LOADINGS } \\
\hline $\begin{array}{l}\text { BL } \\
\text { (Body Language) }\end{array}$ & $\begin{array}{l}\text { RE } \\
\text { (Relaxation) }\end{array}$ & -0.809 & -0.803 & -0.006 & $0.7 \%$ \\
\hline $\begin{array}{l}\text { BL } \\
\text { (Body Language) }\end{array}$ & $\begin{array}{l}\text { MO } \\
\text { (Movement) }\end{array}$ & -0.793 & -0.670 & -0.123 & $15.5 \%$ \\
\hline $\begin{array}{l}\text { BL } \\
\text { (Body Language) }\end{array}$ & $\begin{array}{l}\text { FA } \\
\text { (Facial) }\end{array}$ & 0.323 & not sig. & n.a. & n.a. \\
\hline $\begin{array}{l}\text { SW } \\
\text { (Spoken Word) }\end{array}$ & $\begin{array}{l}\text { OR } \\
\text { (Organization) }\end{array}$ & 0.877 & 0.892 & -0.015 & $-1.7 \%$ \\
\hline $\begin{array}{l}\text { SW } \\
\text { (Spoken Word) }\end{array}$ & $\begin{array}{l}\text { ST } \\
\text { (Style) }\end{array}$ & 0.811 & 0.797 & 0.014 & $1.7 \%$ \\
\hline $\begin{array}{l}\text { SW } \\
\text { (Spoken Word) }\end{array}$ & $\begin{array}{l}\text { T0 } \\
\text { (Tone) }\end{array}$ & 0.623 & 0.553 & 0.07 & $11.2 \%$ \\
\hline $\begin{array}{l}\text { AUT } \\
\text { (Authentic Perception) }\end{array}$ & $\begin{array}{l}\text { EX } \\
\text { (External Influence) }\end{array}$ & 0.668 & 0.719 & -0.051 & $-7.6 \%$ \\
\hline $\begin{array}{l}\text { AUT } \\
\text { (Authentic Perception) }\end{array}$ & $\begin{array}{l}\text { AU } \\
\text { (Self-alienation) }\end{array}$ & 0.294 & 0.197 & 0.097 & $33.0 \%$ \\
\hline $\begin{array}{l}\text { AUT } \\
\text { (Authentic Perception) }\end{array}$ & $\begin{array}{l}\text { AL } \\
\text { (Self-authentication) }\end{array}$ & 0.502 & 0.561 & -0.059 & $-11.8 \%$ \\
\hline \multicolumn{6}{|l|}{ REGRESSIONS } \\
\hline $\begin{array}{l}\text { AUT } \\
\text { (Authentic Perception) }\end{array}$ & $\begin{array}{l}\text { BL } \\
\text { (Body Language) }\end{array}$ & -0.195 & -0.249 & 0.054 & $-27.7 \%$ \\
\hline $\begin{array}{l}\text { AUT } \\
\text { (Authentic Perception) }\end{array}$ & $\begin{array}{l}\text { SW } \\
\text { (Spoken Word) }\end{array}$ & 0.604 & 0.517 & 0.087 & $14.4 \%$ \\
\hline
\end{tabular}

\section{RESULTS AND DISCUSSION}

Personal interaction factors affect perceptions of authenticity, which, in turn, affects sales effectiveness. The current study highlighted that male and female perceptions of salesperson authenticity are driven by variant personal interaction factors. Male consumers' perceptions of authenticity are, in high involvement product situations, more heavily influenced by the spoken word. Female consumers' perceptions of authenticity are, in high involvement product situations, more heavily influenced by body language.

Specific results associated with the study's hypotheses are as follows:
H1: For male customers (as compared to female customers), the body language (BL) of the salesperson has a relatively lower influence $(-27.7 \%)$ on perceptions of salesperson authenticity (AUT). Therefore, Hypothesis $\mathrm{H} 1$ is supported. Body language (BL) exerts greater influence on female perceptions of salesperson authenticity (see Table 4).

Additional body language results include the finding that male perceptions of body language are more heavily influenced by body movement (15.5\%) and facial expressions. For female customers, facial 
expression (FA) did not significantly impact perceptions of body language.

H2: For male customers (as compared to female customers), the spoken word (SW) has a relatively higher influence $(14.4 \%$ ) on perceptions of salesperson authenticity (see Table 4). This finding supports Hypothesis $\mathrm{H} 2$. The spoken word has a smaller influence on female perceptions of salesperson authenticity than it does on male perceptions of authenticity.

Regarding body language, the current study found that not only do the genders differ in relation to the relative influence of body language on perceptions of salesperson authenticity, but they also differ in relation to the interpretation of body language. Male interpretations of body language are more heavily influenced by large-scale body movement and facial expressions. Females, on the other hand, are more holistic in their interpretation of body language. The current study's finding accords with past research regarding gender-based interpretations of body language. Females, on average, are much likelier to perceive and understand physical nuance or micro-signals, while males are usually less adept at interpreting these displays (Briton \& Hall, 1995; Hall, 1984; Guadagno \& Cialdini, 2007; Kotlyar \& Ariely, 2013; LaFrance \& Henley, 1994; McClure, 2000; Rosen et al., 2008).

There are several implications associated with the current study's body language findings. First, sales managers and salespeople should be taught that body language substantively impacts consumer perceptions of authenticity. Salesperson training should include crossgender feedback in which male and female trainers or co-workers provide interpretive body-language feedback. Filmed role-plays are a particularly useful format for enabling circumspect body-language assessment and feedback (Hughes, Ginnett, \& Curphy, 1993; Parker, Pettijohn, \& Luke, 1996). Feedback from both male and female reviewers should be provided so that salespeople develop an understanding of the manner in which the same gestures or body-language expressions may elicit variant responses.

A second implication of the current study's body-language finding is that males and females should not assume that they understand the body language of the other gender correctly. The fact that body language varies in its effect on gender-based perceptions of authenticity implies that the genders do not interpret body language in the same manner. Further research is required to better understand the specific nature of this difference, but the fact that a difference exists should be consciously recognized and considered by sales managers and salespeople.

Regarding the spoken word, the current study confirmed prior findings that males are generally more reliant on the spoken word during high involvement product purchase situations (Guadagno \& Cialdini, 2007). In the current study's automotive purchase situation, male consumers relied more heavily on central cues (the spoken word) to inform their perceptions of salesperson authenticity. The implication for female salespeople in high-involvement product situations is that they must refrain from dismissing central cues (the spoken word) in favour of peripheral cues (body language). Conversely, male salespeople must be careful to avoid an overreliance on the spoken word when dealing with female customers.

Although the current study's methodology resulted in acceptable reliability and validity, limitations exist. First, the utilization of a convenience sample resulted in a non-normal age and gender distribution of sampled participants. Second, the study's location may limit its generalizability. The experiment was conducted using an automotive dealership in the United States. International variations in the automotive-buying process may impact whether the study's findings can be generalized to other business markets and cultural environments (see also Říha, Heinze \& Stros, 2017; Stros, Říha \& Möslein-Tröppner, 2018; Stros, Heinze \& Říha, 2017). Finally, only a small minority of the sampled university participants were current automobile customers. However, considering that most of the sampled participants were potential automotive customers, the authors do not view this limitation as significant.

\section{REFERENCES}

Abele, A.E. (2000). The Dual-impact Model. In Eckes, T., and Trautner, H.M. (Eds) The 
Development Social Psychology of Gender. London. Lawrence Erlbaum Associates.

Algera, P.M. \& Lips-Wiersma, M. (2012). Radical authentic leadership: Co-creating the conditions under which all members of the organization can be authentic. The Leadership Quarterly, 23, 1, 118-131.

Avolio, B.J. \& Gardner, W.L. (2005). Authentic leadership development: Getting to the root of positive forms of leadership. The Leadership Quarterly, 6, 3, 801-823.

Avolio, B.J., Gardner, W.L, Walumbwa, F.O., Luthans, F., \& May, D.R. (2004). Unlocking the mask: a look at the process by which authentic leaders impact follower attitudes and behaviours. The Leadership Quarterly, $15,6,801-823$.

Barrett-Lennard, G.T. (1998). Carl Rogers' helping system: Journey and substance. London. Sage.

Briton, N.J. \& Hall, J.A. (1995). Beliefs about female and male nonverbal communication. Sex Roles, 32, 79-90.

Brown, T.A. (2015). Confirmatory factor analysis for applied research. 2nd edition, New York. Guilford Press.

Bureau of Labour Statistics (2019). Labour force statistics from the current population survey. Bureau of Labour Statistics, Washington, DC. US Department of Labour.

Bush, A.J., Smart, D., \& Nichols, E.N. (2002). Pursuing the concept of marketing productivity Introduction to the JBR Special Issue on Marketing Productivity. Journal of Business Research, 55, 5, 343-347.

Buss, D.M. (1995). Psychological sex differences: origins through sexual selection. American Psychologist, 50, 164-168.

Coleman, J.C. (1949). Facial expression of emotion. Psychological Monographs, 63, 1, 296.

Costa, P.T., Jr., Terracciano, A., \& McCrae, R.R. (2001). Gender difference personality traits across cultures: Robust and surprising findings. Journal of Personality and Social Psychology, 81, 2, 322-331.
Davitz, J.R. (1964). A review of research concerned with facial and vocal expressions of emotion. The Communication of Emotional Meaning, New York. McGrawHill.

Diddams, M. \& Chang, G.C. (2012). Only human: Exploring the nature of weakness in authentic leadership. The Leadership Quarterly, 23, 3, 593-603.

Donoho, C., Heinze, T., \& Kondo, C. (2012). Gender differences in personal selling ethics evaluations: Do they exist and what does their existence mean for teaching sales? Journal of Marketing Education, 34, 1, 55-66.

Eagly, A.H. (1987). Sex differences in social behaviour: A social-role interpretation. Hillsdale, NJ. Erlbaum.

Else-Quest, N.M., Hyde. J.S., Goldsmith, H.H., \& Van Hulle, C.A. (2006). Gender differences in temperament: a meta-analysis. Psychological Bulletin, 132, 33-72.

Erevelles, S. \& Fukawa, N. (2013). The role of affect in personal selling and sales management. Journal of Personal Selling \& Sales Management, 18, 1, 7-24.

Freud, S. (1925). The standard edition of the complete psychological works of Sigmund Freud: (J. Strachey, Ed. \& Trans. Vol. 19). London. Hogarth Press.

Freud, S. (1938). Abriss der Psychoanalyse. Frankfurt. Fischer.

Grant, J. (1988). Women as managers: What they can offer to organizations. Organizational Dynamics, 16, 56-63.

Guadagno, R.E. \& Cialdini, R.B. (2007). Persuade him by email, but see her in person. Computers in Human Behaviour, 23, 9991015.

Hair, J.F., Black, W.C., Babin, B.J., \& Anderson, R.E. (2009). Multivariate Data Analysis. 7th edition. London. Prentice-Hall International.

Hall, J. (1984). Nonverbal Sex Differences: Communication Accuracy and Expressive Style. Baltimore. John Hopkins University Press.

Hall, J. (2006). Nonverbal behaviour, status, and gender: How do we understand their 
relations? Psychology of Women Quarterly, 30, 384-391.

Howell, D. (2007). The analysis of missing data. London. Sage.

Hu, L. \& Bentler, P. M. (1999). Cut-off criteria for fit indexes in covariance structure analysis: Conventional criteria versus new alternatives. Structural Equation Modelling, 6, 1-55.

Hughes, R., Ginnett, R., \& Curphy, G. (1993). Leadership: enhancing the lessons of experience. Homewood, IL. Irwin.

Hyde, J.S. (2005). The gender similarities hypothesis. American Psychologist, 60, 581592.

International Labour Organization (2018). World employment social outlook. Geneva, Switzerland. International Labour Office.

Kiecker, P., Palan, K.M., \& Areni, C.S. (2000). Different ways of seeing: how gender differences in information processing influence the content analysis of narrative texts. Marketing Letters, 11, 1, 49-65.

Kernis, M.H. (2003). Toward a conceptualization of optimal self-esteem. Psychological Inquiry, 14, 1-26.

Kline, R.B. (2010). Principles and practice of structural equation modelling. 3rd edition. New York. Guilford Press.

Koppensteiner, M. \& Grammer, K. (2011). Body movements of male and female speakers and their influence on perceptions of personality. Personality and Individual Differences, 51, 743-747.

Kotlyer, I. \& Ariely, D. (2013). The effect of nonverbal cues on relationship formation. Computers in Human Behaviour, 29, 544551.

LaFrance, M. \& Henley, N.M. (1994). On oppressing hypotheses: Or differences in nonverbal sensitivity revisited. In H.L. Raadtke \& H.J. Stam (Eds), Power/Gender: Social Relations in Theory and Practice. London. Sage.

Lee, Y., Heinze, T., Donoho, C., Fournier, C., Jalal, A.A., Cohen, D. and Hennebichler, E. (2018). An International Study of Culture, Gender, and Moral Ideology on Sales Ethics Evaluations: How Should Educators Respond? Journal of Marketing Education, 40, 3, 196-210.

Lever, J. (1978). Sex differences in the complexity of children's play and games. American Sociological Review, 43, 471-783.

Little, R. \& Rubin, D.B. (2002). Statistical Analysis with Missing Data. 2th edition. New York. Wiley.

Little, T.D. (2013). Longitudinal structural equation modelling. New York. Guilford Press.

Maccoby, E.E. \& Jacklin, C.N. (1974). The Psychology of Sex Differences. Stanford, CA. Stanford University Press.

McClure, E.B. (2000). A meta-analytic review of sex differences in facial expression processing and their development in infants, children, and adolescents. Psychological Bulletin, 126, 3, 424-453.

McQuiston, D.H. \& Morris, K.A. (2009). Gender differences in communication: implications for salespeople, Journal of Selling \& Major Account Management, 9, 1, 54-64.

Mehrabian, A. (1969). Methods \& design: Some referents and measures of nonverbal behavior. Journal of Behaviour Research Methods and Instruments, 1, 6, 203-207.

Meyers-Levy, J. \& Maheswaran, D. (1991). Exploring differences in males' and females' processing strategies. Journal of Consumer Research, 18, 1, 63-70.

Meyers-Levy, J. \& Sternthal, B., (1991). Gender differences in the use of message cues and judgments. Journal of Marketing Research, 28, 84-96.

Meyers-Levy, J. \& Zhu, R. (2010). Gender differences in the meaning's consumers infer from music and other aesthetic stimuli. Journal of Consumer Psychology, 20, 495507.

Michalski, R.L. \& Schackelford, T.K. (2010). Evolutionary personality psychology: Reconciling human nature and individual differences. Personality and Individual Differences, 48, 509-516. 
Neider, L.L. \& Schriesheim, C.A. (2011). The authentic leadership inventory (ALI): Development and empirical tests. The Leadership Quarterly, 22, 6, 1146-1164.

Parker, R., Pettijohn, C., \& Luke, R. (1996). Sales representatives and sales professors: $A$ comparative analysis of sales training perceptions, topics and pedagogy. Marketing Education Review, 6, 3, 41-50.

Papyrina, V. (2015). Men and women watching and reading: Gender and information processing opportunity effects in advertising. Journal of Marketing Communications, 21, 2, 125-143.

Plouffe, C.R., Williams, B., and Wacliner, T. (2008). Navigating difficult waters: Publishing trends and scholarship in sales research. Journal of Personal Selling \& Sales Management, 28, 1, 79-92.

Pool, R. (1994). Eve's rib: Searching for the biological roots of sex differences. New York. Crown.

Putrevu, S., Tan, J., \& Lord, K.R. (2004). Consumer responses to complex advertisements: The moderating role of need for cognition, knowledge, and gender. Journal of Current Issues and Research in Advertising, 26, 1, 924.

R Development Core Team (2012). R: A Language and Environment for Statistical Computing, R Foundation for Statistical Computing, Vienna, Austria. ISBN 3-90005107-0, URL http: //www.R-project.org/.

Rego, A., Sousa, F. Marques, C., \& Pina e Cunha, M. (2011). Authentic leadership promoting employees' psychological capital and creativity. Journal of Business Research, 65, 3, 429-437.

Samovar, L.A. \& Porter, R.E. (2003). Intercultural communication: A reader, 10 th ed. Wadsworth, Belmont.

Říha, D., Heinze, T. \& Stros, M. (2017). Intercultural Variations in Personal Sales Factors in the Czech and U.S. Automotive Markets: Practical Implications for Marketing. Central European Business Review, 6, 1, 26-47.
Rosen, L.D., Cheever, N.A., Cummings, C., \& Felt, J. (2008). The impact of emotionality and self-disclosure on online dating versus traditional dating. Computers in Human Behaviour, 24, 2124-2157.

Rosseel, Y. (2012). Lavaan: An R Package for Structural Equation Modelling. Journal of Statistical Software, 48, 2, 1-36.

Sheth, J.N. \& Sisodia, R.S. (2002). Marketing productivity Issues and analysis. Journal of Business Research, 55, 5, 349-362.

Smith, A. \& Rogers, V. (2000). Ethics-related responses to specific situation vignettes: Evidence of gender-based differences and occupational socialization. Journal of Business Ethics, 28, 73-86

Stros, M., Heinze, T., \& Říha, D. (2017). Relevance of Personal Interaction Factors between Customers and Sales Representatives in the Automotive Business. Journal of Applied Marketing Theory, 7, 1, 33-55.

Stros, M.; Říha, D., \& Möslein-Tröppner, B. (2018). The Role of Gender in Salesperson Perception, Marketing Sciences \& Inspirations, XIII, 3, 11-23.

Stros, M.; Říha, D., Říhová, E., \& Lim, L.L.K. (2019). Personal Sales Success Factors in a Wealthy Automotive Market Environment. Journal of Eastern European and Central Asian Research, 6, 1, 25-39.

Tate, B. (2009). A longitudinal study of the relationships among self-monitoring, authentic leadership, and perceptions of leadership. Journal of Leadership and Organizational Studies, 15, 1, 16-29.

Twenge, J.M. (1997). Changes in masculine and feminine traits over time: A meta-analysis. Sex Roles, 36, 305-325.

Vrugt, A. \& Luyerink, M. (2000). The contribution of bodily posture to gender stereotypical impressions. Social Behavior and Personality, 28, 1, 91-104.

Walumbwa, F.O., Hui Wang, P.W., Schaubroeck, J., \& Avolio, B.J. (2010). Psychological processes linking authentic leadership to follower behaviours. The Leadership Quarterly, 21, 5, 901-914. 
Weisgerber, C.A. (1956). Accuracy in judging emotional expressions as related to college entrance test scores. Journal of Social Psychology, 44, 233-239.

Wood, A. M., Linley, P. A., Maltby, J., Baliousis, M., \& Joseph, S. (2008). The authentic personality: A theoretical and empirical conceptualization and the development of the Authenticity Scale. Journal of Counselling Psychology, 55, 3, 385-399.

Zell, E, Krizan, Z., \& Teeter. S.R. (2015). Evaluating gender similarities and differences using metasynthesis. American Psychologist, 70, 10-20.

\section{ABOUT THE AUTHORS}

Michel Stros, email: michael.stros@ffhs.ch

Dr. Michael Stros is the Head of the Marketing Group and teaches at the University of Applied Sciences and Arts of Southern Switzerland (SUPSI), Fernfachhochschule Schweiz, Brig, Switzerland. His main research interests focus on Pharmaceutical Marketing and Personal Sales. Besides of his academic activities, Michael is a Marketing Consultant and Sales Trainer. In his previous professional activities, Michael was engaged as a Product and Sales Manager for International Biotech Companies. Head of the Marketing Group at the University of Applied Sciences and Arts of Southern Switzerland, Fernfachhochschule Schweiz (FFHS).

Dr. Timothy Heinze is a Professor of Marketing at California State University, Chico, where he founded and directed the Seufferlein Sales Program. Previous professional experience includes marketing positions at Ford Motor Company. Research interests include sales ethics, gender, and sales pedagogy.

Dr. David Ǩíha is an Assistant Professor at the Department of Marketing of the Faculty of Business Administration at the University of Economics, Prague and from 2013 also at the University of Applied Sciences Upper Austria School of Management / Steyr. Education at the University of Economics, College of Business and Management Faculty of Escuela Superior de Marketing y Administración Barcelona supported within the study internships in Finland, Mexico, Austria and the UK. His practical experience is in sales and managerial positions in international companies and through consulting activities.

Dr. Bodo Möslein-Tröppner has many years of experience in industry and trade. His main focus in research and teaching is in the areas of supply chain management, process management and market research as well as new learning methods. He is Professor at Duale Hochschule Ravensburg (DHBW), Germany.

Dr. Elena Říhová is an assistant of professor at Skoda Auto University, Mlada Boleslav, Czech Republic. She received the Ph.D. degree from the University of Economics in Prague, Czech Republic, in 2016. She is currently with the Czech Technical University and Skoda Auto University. Her main research is focused on Fuzzy Clustering and Factor Analysis. Her research interests also include multivariate statistical methods.

Dr. Lynn L. K. Lim is a Professor of Global Consumer Research and the Programme Head for the Master of Science (MSc) in International Management at the School of Business, University of Applied Sciences and Arts Northwestern Switzerland (FHNW), Olten. 